\title{
Occurrence of a DNA $\beta$-containing begomovirus associated with leaf curl disease of kenaf (Hibiscus cannabinus L.) in India
}

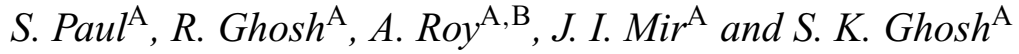

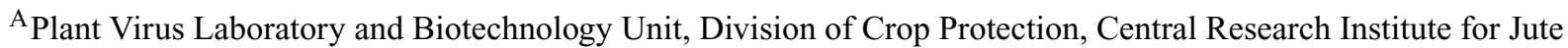 \\ and Allied Fibres, Kolkata-700120, West Bengal, India. \\ ${ }^{\mathrm{B}}$ Corresponding author. Email: anirbanroy75@yahoo.com
}

Abstract. The association of a begomovirus, which has satellite DNA $\beta$, with leaf curl disease of kenaf has been detected for the first time.

Kenaf (Hibiscus cannabinus L.) is a potentially valuable industrial crop due to its fibre content, medicinal value and effective use in the paper industry (Duke 1983). The USDA recognises kenaf as the best non-woody papermaking plant. The crop is attacked by several viral diseases
(Brunt et al. 1996; Jones and Behncken 1980). In recent years a disease causing leaf curl symptoms on kenaf has been observed in different parts of India. The infected plants showed curly leaves at early stages, and then gradually became distorted and puckered (Fig. 1). The height of the

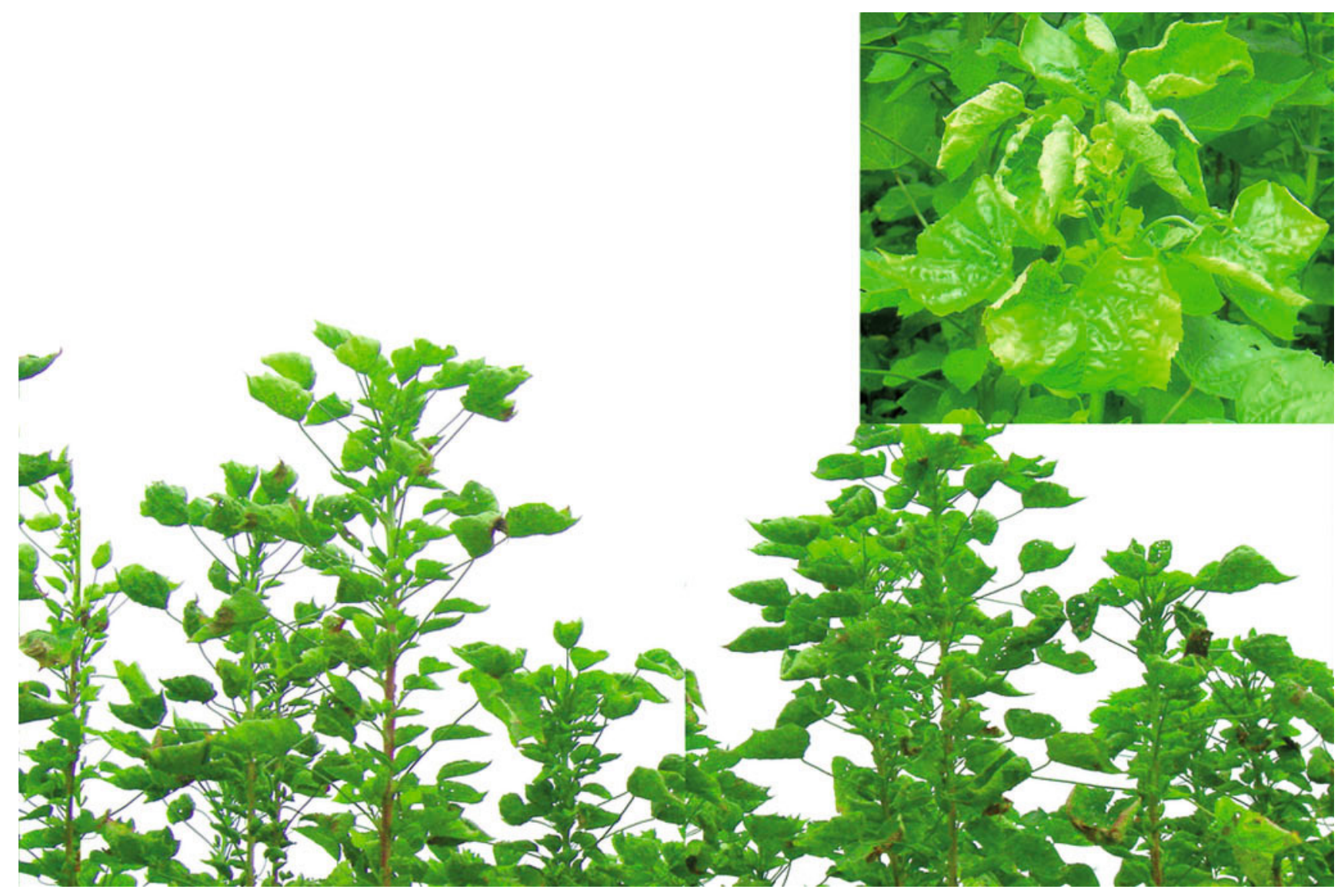

Fig. 1. Leaf curl disease-infected kenaf in the field with a close view of symptoms in leaves (inset). 
infected plants was also progressively reduced. A survey was carried out at three villages located in the Bahraich district of Uttar Pradesh, India, and records were taken at 100 days after sowing. Incidence, disease severity (proportion of affected leaves) and plant height reduction were recorded. Leaves from plants showing typical symptoms were collected for molecular analysis.

Disease incidence, disease severity and height reduction averaged 22,66 , and $25 \%$, respectively from a total 1203 plant surveyed. Transmission electron microscopy of typical symptomatic leaves of kenaf using $2 \%$ uranyl acetate revealed the presence of geminate particles measuring $18 \times 27 \mathrm{~nm}$. Total DNA obtained from infected leaves gave a strong Southern hybridisation signal after hybridisation with a Cotton leaf curl Rajasthan virus DNA A (GenBank accession number NC_003199) probe after stringent washing (three washes) with $2 \times \mathrm{SSC}$ and $0.1 \% \mathrm{SDS}$ at $65^{\circ} \mathrm{C}$. The healthy samples did not give a hybridisation signal. Using PCR with universal DNA $\beta$ (Briddon et al. 2002) and coat protein primers (Jose and Usha 2000), a $\sim 1.3 \mathrm{~kb}$ fragment corresponding to DNA $\beta$ and a $\sim 0.77 \mathrm{~kb}$ fragment corresponding to the coat protein gene of DNA A were amplified from DNA samples obtained from 20 randomly selected plants from ten different fields showing leaf curl symptoms. This is the first record of a begomovirus, which has DNA A along with a satellite DNA $\beta$, being associated with leaf curl disease of kenaf in India.

\section{Acknowledgements}

Authors are grateful to Director CRIJAF, for his keen interest during the present investigation and Dr V. G. Malathi (IARI) for providing DNA A probe. The first two authors are also grateful to ICAR for providing financial assistance during the tenure of which this work was carried out.

\section{References}

Briddon RW, Bull SE, Mansoor S, Amin I, Markham PG (2002) Universal primers for the PCR-mediated amplification of DNA $\beta$ : a molecule associated with some monopartite begomoviruses. Molecular Biotechnology 20, 315-318. doi: 10.1385/MB:20:3:315

Brunt AA, Crabtree K, Dallwitz MJ, Gibbs AJ, Watson L, Zurcher EJ (Eds) (1996) 'Plant viruses online: description and lists from the VIDE Database.' Available at http://images.fs.uidaho.edu/vide/ famly082.htm\#Hibiscus\%20cannabinus (verified 9 October 2006)

Duke JA (1983) 'Handbook of energy crops.' Available at http://www. hort.purdue.edu/newcrop/duke_energy/Hibiscus_cannabinus.html (verified 9 October 2006)

Jones DR, Behncken GM (1980) Hibiscus chlorotic ringspot, a widespread virus disease in the ornamental Hibiscus rosa-sinensis. Australasian Plant Pathology 9, 4-5. doi: 10.1071/APP9800004

Jose J, Usha R (2000) Extraction of Geminiviral DNA from a highly mucilaginous plant (Abelmoschus esculentus). Plant Molecular Biology Reporter 18, 349-355.

Received 1 August 2006, accepted 27 September 2006 